\title{
АНАДИЗА НА ПОСТОЕЧКАТА СОСТОЈБА СО ПРОЦЕСОТ НА ДЕИНСТИТУЦИОНАДИЗАЦИЈА ВО РЕПУБЛИКА МАКЕДОНИЈА СО ФОКУС НА 10 ОПШТИНИ
}

\section{Резиме}

Системот за социјална заштита на Република Македонија се состои од центри, институции, мерки, активности и норми реализирани во рамките на остваруватьето на правата и обезбедуваньто услуги на граѓаните во областа на социјалната заштита. Системот се надградува преку експертиза на ицентрите за социјјална заштита (кои спроведуваат развојни програми и работат на професионална специјализација на работниците во зависност од потребите на корисниците и меѓународните стандарди), следене на состојбите и планиране на работата, водеюе евиденција како и спроведуватье надзор и истражуватье во оваа област.

Процесот на деинституц̧ионализациија на иицата со попреченост ќе биде невозможен без силна мрежа на даватели на услуги, приватниот сектор од тој регион, бидејќ двете се релевантни засегнати страни за развој на модели на образование, вработуватье, социјални и здравствени услуги кои се во функциија за да се олесни независното живеене на лииа со попреченост.

Преку овој пристап, развиени се приспособени модели, кои се однесуваат на потребите на цеелните лицุа од институцุиите, како и претставниции на лицата со попреченост, во сите десет опитини и тие треба да бидат вклучени во националните политики. Поконкретно, со приспособуване на протоколи, упатства, модули за обука за да се обезбеди пристапност и прифатливост на услугите за лицза со попреченост во над 10 споменати опитини, ќе се отстранат бариерите за постојните услуги и ќе се постигне највисоко можно ниво на усхуги за хица со попреченост. ${ }^{1}$

Клучни зборови: ДЕИНСТИТУЦИОНАЯИЗАЦИЈА, ПУЃЕ СО ПОПРЕЧЕНОСТ, СИСТЕМ НА СОЦИЈАЛНА ЗАШТИТА

\section{Вовед}

Резултати од процесот на деинституционализација на лицата со попреченост досега:

\footnotetext{
${ }^{1}$ Истражувањето е направено во рамки на проектот Поддршка на модернизацијата и деинституционализацијата на социјалните услуги инплементиран од, Делегација на Европска Унија во РСМ
} 
- Децата и возрасните со попреченост имаат корист од подобрениот систем на поддршка што им овозможува да ги напуштат затворените институции за живеење и да водат независен живот во заедницата;

- Развиени се услуги засновани на заедницата и подготвени индивидуални планови за вработување за да им помогнат на возрасните од Бања Банско во реинтеграцијата во општеството;

- Потребна е обука на вработените во образованието во Скопје, Куманово, Велес, Штип, Демир Капија, Кавадарци, Струмица, Тетово, Охрид, Битола за да им се овозможи да дизајнираат и да обезбедат програми за вклучено образование за деца со попреченост;

- Воспоставена е професионална заедница на практики за инклузивно образование;

- Развиени се алатки за обука и се спроведува обука до згрижувачки семејства за да се подобри грижата што се обезбедува на децата со попреченост;

- Зголемен е капацитетот на лицата со попреченост да се залагаат за своите права и лицата со попреченост наоѓаат поголемо прифаќање во нивните локални заедници;

- Спроведени се иницијативи за подигање на свеста, вклучително прирачници за обука, за разбирање на нивните права и мапирање на можностите за алтернативна (вонинституционална) грижа за подобро вклучување во општеството;

Партнер за изготвување лични планирања може да биде Филозофскиот факултет од Универзитетот „Св. Кирил и Методиј“ во Скопје кој потпиша договор за соработка со Министерството за труд и социјална политика. Студентите од институтите за специјално образование и рехабилитација, социјална работа и социјална политика и психологија можат да работат заедно низ целата земја.

- Механизмите за поддршка се дизајнирани за биолошки и згрижувачки семејства за подобро да одговорат на раздичните потреби на децата со попреченост, притоа обезбедувајќи фокус на социјалната вклученост;

- Документирани се добри практики за социјална вклученост и интегрирана поддршка, вклучително пристап до недискриминаторски, здравствено-социјални услуги што одговараат на пол, инклузивно образование и инклузивен пазар на трудот;

- Обезбедена е поддршка за негувателките во биолошките и згрижувачките семејства за да се подобри квадитетот на грижата за децата и возрасните со попреченост.

На секој институт, еден професор ќе биде ментор на работата и секој студент ќе има задача да доставува квартални и годишни извештаи.

За вработените во центрите за социјална работа најголем товар е задачата „управување со случаи“, која оваа година е одговорност на профе- 
сионалците воведени за прв пат и претставува дополнително време и напори. Воведувањето на оваа задача се смета за најзабележителен проблем со недоволниот број на вработени во центрите за социјална работа. Капацитетите на вработените во ЦСР се ограничени. Тие понатаму укажуваат на потребата од темелна и практична обука за примена на овој метод на работа. Потребно е да се воведат услуги по мерка на корисникот.

\section{ПОТРЕБА ОД АНАЯИЗА ВО ГРАДОВИТЕ ЗА ОВАА ИСТРАЖУВАЊЕ}

- Сите градови имаат потреба од развој или зголемување на центри за дневна грижа, социјални клубови, згрижувачки семејства, мали групни домови, единици за поддршка, дични асистенти и центри за рана интервенција;

- Иако процесот на деинституционадизација не е нов и веќе се спроведени низа активности и кампањи, сепак постои потреба од тековни информативни кампањи за промена на јавната свест. Сите укажуваат на потребата од зголемување на бројот на вработени во ЦСР и зголемување и опремување на профилите на дневните центри како гаранција за успешно спроведување на работните одговорности. Сите истакнуваат дека дуѓето што живеат во руралните области не се третираат еднакво поради недостаток на услуги во заедницата, но исто така и на организиран превоз за оние кои можат да го користат во урбаните области;

- Градовите кои се опфатени во ова истражување имаат неколку згрижувачки семејства и мали групни домови, но кога станува збор за лица со попреченост, бројот е намален или воопшто нема;

\section{Приоритетите кои ги наведуваат општините во следниот период се:}

\section{Битола}

Отворање Дневен центар за возрасни со попреченост над 18/26 години, кои во моментов го посетуваат Дневниот центар каде старосната граница е до 18/26 години, така што нема слободни работни места за помладите луѓе на кои им е потребна оваа услуга;

- Отворање Дневен центар за рана интервенција на деца со попреченост, до шестгодишна возраст, каде што ќе се понуди индивидуална рехабилитација за подобрување на состојбата на најмладите;

- Отворање Дневен центар или привремено сместување за деца во ризик поради големиот број деца на кои им е потребна оваа услуга;

- Обезбедување лични асистенти и толкувачи на знаковен јазик за да им помагаат на дицата со оштетен слух низ институциите; 
- Обезбедување интервентни згрижувачки семејства;

- Обезбедување дополнителен број згрижувачки семејства заради згрижување луѓе во нивната општина.

\section{Велес}

- Лична помош на стари дица и дица со попреченост. Досега се примени над 130 апликации за лични асистенти за лица со церебрална парализа, лица со оштетен вид, лица со моторни нарушувања и стари дица;

- Обезбедување згрижувачки семејства во општината за дицата кои имаат потреба од нив да не бидат испратени во семејства во други општини;

- Отворање мали групни домови во општината за луѓето со потреба да не се преселат во мали групни домови или институции во други општини.

\section{Демир Капија}

- Охрабрување на семејствата во општината да се грижат за децата, бидејќи во моментов нема згрижувачки семејства;

Отворање Дневен центар за дица со попреченост, бидејќи такви центри нема ниту во Демир Капија ниту во Неготино;

- Развој на идеја за искористување на празните капацитети на Специјалната установа - една од потребите за сместување стари лица може да се реализира со претворање на канцеларијата во дом за стари дица.

\section{Кавадарци}

- Отворање Дневен центар за дица со тешка попреченост над 18 години, бидејќи во моментот постои Дневен центар за деца;

- Обезбедување интервентни згрижувачки семејства во општината, за оние што имаат потреба да бидат згрижени додека даваат други форми на социјална поддршка;

- Отворање мали групни домови во општината за луѓето со потреба да не се преселат во мали групни домови или во институции во други општини.

\section{Куманово}

- Отворање Дневен центар за рехабилитација на лица со церебрална парадиза, каде што ќе добијат соодветна интервенција и поддршка. 


\section{Охрид}

- Отворање Дневен центар за деца со тешка попреченост, на возраст од 6 до 18 години, кои поради сериозноста на попреченоста не се во можност во моментов да имаат пристап до редовно образование, поради недостаток на капацитет на образовниот систем;

- Обезбедување згрижувачки семејства во општината за дицата кои имаат потреба од згрижувачки семејства да не бидат испратени во семејства во други општини;

- Отворање мади групни домови во општината за луѓето со потреба да не се преселат во мади групни домови иди во големи институции во други општини.

\section{Скопски плански регион}

\section{Аеродром}

- Развој на соодветни услуги за поддршка, но исто така и вклучување деца на возраст од 7 до 18 години, кои од некои причини може да не бидат вкдучени во образовниот процес преку процесот на инклузија;

- Подигање на јавната свест, советување, помош и поддршка за тоа како дицата со попреченост можат да бидат вкдучени во заедницата, образованието, пазарот на трудот за општата популација и за дицата со попреченост, како и родителите за важноста на процесот на независност на овие лица;

- Информирање на пошироката јавност, на луѓето во ризик, но исто така и на деловниот сектор за важноста на социјалното претприемништво и развој на истото како можност за интеграција на луѓето на пазарот на трудот и надминување на ризикот од невработеност и материјална несигурност.

\section{Бутел}

- Развијте програми и услуги за превенција на рана интервенција за деца со попреченост од 0 до 7 години, кои ќе вкдучуваат професионален третман, советување и професионална работа со родители на децата и со другите деца во семејството. Овие програми и услуги ќе бидат дел од процесите на интеграција и вклучување и на децата и на семејствата;

- Развој на центри за услуги за деца со попреченост и нивните семејства, особено на возраст од 15 до 26 години (што може да се користи како ресурсен центар од ЈУ Институт за рехабилитација 
на деца и млади). Исто така, тоа би било поддршка за лични асистенти и за други даватели на услуги на оваа популација. Овие центри ќе бидат дел од процесите на интеграција и вклучување и на децата и на семејствата;

- Обезбедување одржливост на групно живеење со поддршка на станбени единици за лица со интелектуална попреченост над 26 години, со отворање друга станбена единица „Мојот дом 3“ во Драчево, со тоа што ќе бидете дел од реинтеграција, на начин на кој сегашните корисници на студентски дом, да бидат сместени во областа и да работат со нив на нивната независност, така што тие ќе научат како да одгледуваат овошје, зеленчук, да чуваат домашни миленици и да им обезбедуваат млеко, месо, јајца, односно производи за храна и за продажба. Тие ќе бидат ангажирани таму, ќе работат и ќе имаат корист од целокупната одржливост на станбените единици и ќе ги намалат трошоците за скапите станбени единици.

\section{Гази Баба}

- Повторно отворање Дневен центар за деца со попреченост, обезбедување човечки и материјални ресурси и долгорочна одржливост.

\section{Ѓорче Петров}

- Отворање регионалната канцеларија на ЦСР Скопје во локалната заедница Даме Груев, наменета за луѓето во општината кои се во социјален ризик и ќе биде место каде што жителите ќе може да бидат информирани, да им бидат понудени информации за услуги, упатување, бесплатна правна помош, каде што ќе може да ги решат своите проблеми и потреби;

- Воведете стручна поддршка и услуги за психосоцијална поддршка за семејства со чденови на семејството во домот Сју Рајдер, за да им помогнат и да ги подржат семејствата во надминување на оваа тешка животна ситуација.

\section{Илинден}

Општината смета дека нема потреба да се воведат нови социјални услуги во општина Илинден. 


\section{Карпош}

- Развој на соодветни услуги за поддршка, но исто така и вклучување деца на возраст од 7 до 18 години, кои од некои причини може да не бидат вклучени во образовниот процес преку процесот на инклузија;

- Отворање дневен центар за деца со попреченост, чии услуги ќе обезбедат помош и поддршка на децата и родителите како услуга во заедницата;

Проши опсегот на даватели на јавни услуги во областа на социјалната заштита, со поголема вклученост на граѓанскиот сектор, кој е флексибилен и поевтин и може да се појави како содиден давател на услуги.

\section{Кисела Вода}

Општината нема потреба од воведување нови социјални услуги поврзани со дица со попреченост во општина Кисела Вода.

\section{Capaj}

- Развој на услугата на асистенти во образование, бидејќи во општината се регистрирани 60 деца со попреченост кои се вкдучени во редовно образование со процесот на инклузивно образование.

\section{Центар}

- Воспоставување услуга, стручна и правна помош и поддршка на граѓаните на општина Центар во рамките на општината за остварување на нивните права, поддршка за надминување на проблемите и ризиците на кои се издожени.

\section{Чаир}

- Развој и имплементација на информации и активности за упатување на жителите на општината за новите форми на услуги во домот и заедницата што можат да ги добијат и кои се нивните придобивки;

- Отворање и развој на услуги во домот и заедницата за дицата со попреченост и нивните семејства за да се обезбеди соодветна поддршка за задоволување на потребите на овие лица, како и за обезбедување поддршка и омена во грижата за родителите на овие деца / лица; 
Обезбедување буџет и одржливост на услугата за образовна помош за деца со попреченост, што е од голема потреба во општина Чаир и со тоа да се обезбеди правилно вкдучување и интеграција на децата во заедницата и во образовниот систем.

\section{Шуто Оризари}

Во општината Шуто Оризари нема потреба да се воведат нови социјални услуги поврзани со лица со попреченост.

\section{Струмица}

Општина Струмица води по својата инклузивност. Општината има самостојни станбени единици за дица со моторни нарушувања деинституционализирани од институтот Бања Банско. Сепак, општината треба да воведе нови социјални услуги:

- Обезбедување згрижувачки семејства во општината за дицата кои имаат потреба од згрижувачки семејства да не бидат испратени во семејства во други општини;

- Отворање мали групни домови во општината за луѓето со потреба да не се преселат во мади групни домови иди во институции во други општини.

\section{Тетово}

- Обезбедување згрижувачки семејства во општината за дицата кои имаат потреба од згрижувачки семејства да не бидат испратени во семејства во други општини;

- Отворање мали групни домови во општината за дуѓето со потреба да не се преселат во мади групни домови или во институции во други општини.

\section{Штип}

- Отворање Дневен центар за дица со моторни нарушувања, кој ќе овозможи рехабилитација, физиотерапија и спортско-рекреативни активности;

- Обезбедување згрижувачки семејства во општината за дицата што имаат потреба од згрижувачки семејства да не бидат испратени во семејства во други општини. 


\section{ЗАКДУЧОК}

Од горенаведените групи на наоди од истражувањето, се појавуваат заеднички заклучоци. Направени се некои напори низ целиот регион за усогласување на законодавството со релевантната меѓународна рамка за човекови права, вклучително и Конвенцијата за правата на детето и Конвенцијата за правата на дицата со попреченост. Како и да е, треба да се работи повеќе за да се концентрираат и усогласат законските одредби за специфичните потреби на дицата со попреченост во сите сфери на животот, да се наведат најдобрите механизми за спроведување на законодавството.

Големи предизвици се идентификувани при спроведување на политиката во пракса.

Нагласените проблеми вклучуваат ограничен капацитет на клучните вработени, слаба координација меѓу владините оддели и државните и локалните власти, како и хроничен недостиг на буџети.

Креирање регистри на податоци се сеиозна загриженост. За многу лица со попреченост се смета дека целосно недостасуваат во јавните регистри. Ниту една од владите нема дефинитивен број на луѓе кои живеат со попреченост. Повеќето имаат неконзистентен пристап кон собирање статистички податоци и не користат ниту универзална дефиниција за попреченост, ниту стандардизирана методологија за да ја проценат во согласност со Конвенцијата за правата на дицата со попреченост.

Во регион со долга историја на издвојување на лицата со попреченост во институциите, продолжуваат напорите за ставање крај на институционализацијата. Сепак, алтернативните услуги за поддршка во заедницата,како дневните центри и специјадистичката поддршка недостасуваат, што им отежнува на децата да го остварат своето право да живеат со своето семејство. Невладините организации или организациите за дица со посебни потреби честопати ги пополнуваат празнините во државните одредби. Како и да е, непредвидливото финансирање значи дека овие услуги можат да ги намалат или запрат во која било точка. Соработка помеѓу овие организации, работа со семејства на локално ниво или промена на политиката, почнува да гради резултати на некои места.

Програмите за идентификување на деца со попреченост на мала возраст и обезбедување рана интервенција се или неконзистентни или непостоечки. Недостатокот на брза и соодветна реакција има долгорочни импликации врз развојот на децата. Институциите и меѓународните организации упатуваат дека сеуште при процената често се зема медицинскиот модел, и сметаат дека треба целосно да се премине кон класификација на функционалноста според МКФ, кој е поддржан од МОН и МТСП наместо да се фокусираат на тоа како секое дете може да биде поддржано за надминување на бариерите во општеството што го ограничуваат. Инклузивното образование се бори; сепак, ова не секогаш значи дека децата со попреченост целосно учествуваат во учењето на часови и во училишниот 
живот, на еднаква основа со другите деца. Потребна е континуирана работа на работна група на законодавци, државни агенции, даватеди на услуги и дица со пречки во развојот и нивните семејства за да дискутираат и да известуваат за потребите на дицата со пречки во развојот.

Здравството е несигурно, при што многу родители се чувствуваат принудени да изберат скапи приватни опции, честопати затоа што немаат доверба во квалитетот на јавното здравство или затоа што дистите на чекање се премногу долги. Семејствата го носат товарот на високите трошоци за нега, а многу семејства се на работ на сиромаштијата. Пристапноста е редовно цитирано прашање.

Јавните простори, учидиштата, здравствените установи и транспортот често не можат да ги користат дицата со попреченост и најчесто не се достапни. Децата со попреченост се изложени на зголемен ризик од насилство и здоупотреба, иако често не им се дава посебна законска или практична заштита.

Дискриминацијата на дицата со попреченост останува распространета. Оние кои се од традиционално маргинализираните групи како Ромите обично се соочуваат со најголема стигма. Ова го спречува нивниот глас да се слушне за прашања од значење за нив и го ограничува нивното целосно учество во сите области од животот.

Извештајот заклучува дека, иако постојат бариери во некои општини кои ги спречуваат целосно да се префрлат на систем за испорака на услуги заснован на заедницата, општините можат да користат голем број стратегии и предлози за да ја елиминираат нивната зависност од институционалната грижа.

Овие стратегии вкдучуваат:

- Изградба на ресурсни мрежи на заедницата и системи за одговор при кризи/итни случаи на заедницата за да се одговори на причините зошто луѓето првично се институционализирани;

- Создавање системи на долготрајна грижа за дицата со попреченост кои се повеќе водени од потрошувачите и вкдучуваат повеќе услуги во домот и заедницата;

- Експериментирање со раздични модеди на плаќање за услуги за лична асистенција, како што се директно плаќање за услуги и ваучери;

- Свикување работна група од законодавци, државни агенции, даватели на услуги и лица со пречки во развојот и нивните семејства за да разговараат и да известуваат за потребите од услуги на дицата со пречки во развојот;

- Воспоставување на државен систем за собирање податоци кој ги идентификува дицата со пречки во развојот, нивните демографски и дични карактеристики и нивните потреби за услуги;

- Насочување средства за функционирање и на институционалните и на општинските служби додека не се развие инфраструктура заснована на заедницата. 


\section{Литература}

Национална стратегија за деинституционализација за Република Македонија 2018 -2027 'Тимјаник' \& Акциски план. (2018) Скопје: Министерство за труд и социјална политика.

Петрески, М., Туманоска, Д. Социјални сервиси во заедницата во Северна Македонија: можности, ризици, потреби (2020) Скопје: Finance Think - Институт за економски истражувања и политики.

Флакер, В., Крстевски, В. Потенцијали за развој на сервиси базирани на заедницата во транзиција од институционална заштита. Техничка поддршка на процесот за деинституционадизација (2017) Проект импдементиран од A.E.S.A. Consortium во партнерство со Alternative Consulting.

Величковски, Р и Чичевалиева, С 2010. Деца со попреченост во Република Македонија, анализа. Скопје: South-Eastern Europe Health Network.

European Commission. 2012c. FYR Macedonia 2012 Progress Report. SWD(2012) 332 final. Retrieved from http://ec.europa.eu/enlargement/pdf/key_documents/2012/package/ mk_rapport_2012_en.pdf

European Commission. 2013c. The former Yugoslav Republic of Macedonia 2013 Progress Report. Retrieved from http://ec.europa.eu/enlargement/pdf/key_documents/2013/package/ brochures/the_former_yugos lav_republic_of_macedonia_2013.pdf

IDSCS (2017) Social protection and inclusion at local level: Volume of monitoring reports. Skopje: Institute for Democracy Societas Civilis.

Ludwig Boltzmann Institute of Human Rights (2010) Analysis of the state of social protection and social inclusion at local level. Skopje: Ludwig Boltzmann Institute of Human Rights.

Josifovska, B. and Petreski, M. (2018) Analysis of the provision of social services at the local level: Results from the monitoring of the Municipalities of Prilep and Dolneni. Policy study no. 23, Skopje: Economic Research and Policy Institute Finance Think.

PI Institute for Social Activities (2017) Overview of social protection services in the Republic of Macedonia: Overview by regions. Skopje: PI Institute for Social Activities

MoLSP (2013) Handbook on development of social services for the vulnerable groups in the local communities. Skopje: Ministry of Labour and Social Policy. 
